Sains Malaysiana 49(4)(2020): 793-800

http://dx.doi.org/10.17576/jsm-2020-4904-08

\title{
Relationship between Volume of Leukoaraiosis Spot and Degree of Tissue Damage: A Quantitative Diffusion Tensor Imaging Study
}

(Hubungan antara Isi Padu Tompok Leukoaraiosis dengan Darjah Kerosakan Tisu: Satu Kajian Kuantitatif Pengimejan Tensor Difusi)

Nur Hartini Mohd TAiB*, Wan Ahmad Kamil Wan Abdullah, Ibrahim LutFi Shuaib, Muhammad NuR SAlihin Yusoff, EnRico Magosso, SuZANa Mat IsA \& AHMAD Hadif ZAidin SAMSUdin

\section{ABSTRACT}

Diffusion tensor imaging (DTI) offers parameter indices, namely, mean diffusivity (MD) and fractional anisotropy (FA) Leukoaraiosis is a brain white matter hyperintensity as observed on fluid-attenuated inversion recovery (FLAIR) images. In this study, we attempt to assess leukoaraiosis at its specific spot using a new parameter, namely, lesion-tonormal appearing white matter ratio (LNR). LNR was then used to investigate the relationship between the volume of leukoaraiosis spot and the degree of tissue damage. This study involved 49 leukoaraiosis subjects who altogether contributed to 274 leukoaraiosis spots. The MD, FA, and volume were measured at each spot. LNR was calculated by comparing the MD values of the spot with those of the surrounding normal-appearing white matter (NAWM). The correlation between MD, FA, and LNR with leukoaraiosis volume was then analysed. The leukoaraiosis tissues generally exhibited higher MD $\left(103.97 \pm 12.32 \times 10^{-5} \mathrm{~mm}^{2} / \mathrm{s}\right)$ and lower FA $(0.31 \pm 0.08)$ values than the NAWM tissues $\left(79.30 \pm 4.76 \times 10^{-5} \mathrm{~mm}^{2} / \mathrm{s}\right.$ and $0.41 \pm 0.09$, respectively). LNR values were found to range from 0.04 to 1.63 . The results showed an insignificant association between the leukoaraiosis volume and LNR $[r=-.055, p=.368]$, whereas a very weak association was shown with $M D[r=-.196, p=.001]$ and $F A[r=.268, p<.001]$. The volume of the leukoaraiosis spot does not necessarily indicate the degree of tissue damage. By using LNR instead of MD, an accurate analysis was performed since the variability of MD for NAWM surrounding the lesion is taken into account.

Keywords: Brain imaging; diffusion tensor imaging; leukoaraiosis; neuroimaging; white matter

\section{ABSTRAK}

Pengimejan tensor difusi menawarkan indeks parameter seperti difusi min (MD) dan anisotropi pecahan (FA). Leukoaraiosis adalah hiperkeamatan jirim putih otak melalui pemerhatian pada imej pemulihan penyongsangan pelemahan cecair (FLAIR). Dalam kajian ini, kami cuba menilai leukoaraiosis pada tompok khususnya menggunakan parameter baru iaitu nisbah lesi-jirim putih yang kelihatan normal (LNR). LNR kemudiannya digunakan untuk mengkaji hubungan antara isi padu tompok leukoaraiosis dan tahap kerosakan tisu. Kajian ini melibatkan 49 subjek leukoaraiosis yang kesemuanya menyumbang kepada 274 tompok leukoaraiosis. MD, FA dan isi padu diukur di setiap tompok. LNR dihitung dengan membandingkan nilai-nilai MD bagi tompok tersebut dengan jirim putih yang kelihatan normal (NAWM) di sekitarnya. Hubungan antara MD, FA dan LNR dengan isi padu leukoaraiosis kemudiannya dianalisa. Tisu leukoaraiosis umumnya menunjukkan nilai-nilai MD yang lebih tinggi $\left(103.97 \pm 12.32 \times 10^{-5} \mathrm{~mm}^{2} / \mathrm{s}\right) \mathrm{dan} \mathrm{FA}$ lebih rendah $(0.31 \pm 0.08)$ berbanding NAWM (masing-masing $79.30 \pm 4.76 \times 10^{-5} \mathrm{~mm}^{2} / \mathrm{s}$ dan $\left.0.41 \pm 0.09\right)$. Nilai LNR didapati dalam julat 0.04 hingga 1.63. Keputusan menunjukkan perkaitan yang tidak signifikan antara isi padu leukoaraiosis dan LNR $[r=-.055, p=.368]$ manakala perkaitan yang sangat lemah dengan MD $[r=-.196, p=$ $.001]$ dan FA $[r=.268, p<.001]$ telah ditunjukkan. Isi padu tompok leukoaraiosis tidak semestinya menunjukkan tahap kerosakan tisu. Dengan menggunakan LNR berbanding MD, analisis yang tepat telah dilakukan kerana kebolehubahan MD bagi NAWM yang mengelilingi lesi telah diambil kira.

Kata kunci: Jirim putih; leukoaraiosis; pengimejan neuro; pengimejan otak; pengimejan tensor difusi

\section{INTRODUCTION}

Leukoaraiosis is detected as a hyperintense area on T2-weighted and fluid-attenuated inversion recovery (FLAIR) magnetic resonance (MR) images of the brain white matter. It is often observed as patchy and irregular in shape. Leukoaraiosis development is associated with various risk factors such as age, hypertension and diabetes mellitus (Grueter \& Schulz 2011) as well as various mechanisms such as ischemia, blood-brain barrier dysfunction and changes in plasma $\beta$ amyloid (O'Sullivan 
2008). Leukoaraiosis is usually assessed using a visual rating on FLAIR images. There are many types of visual rating scales, which are based on the degree, shape and distributions of the lesions in the brain (Fazekas et al. 2002; Pantoni et al. 2002).

Diffusion tensor magnetic resonance imaging (DT-MRI) or diffusion tensor imaging (DTI) provides quantitative information that assists in understanding both normal and pathological tissues at the molecular level. Two DTI parameter indices that are commonly used are mean diffusivity (MD) and fractional anisotropy (FA). MD gives information about the mean displacement of water diffusion in white matter tissues, whereas FA provides detailed information on the directionality of the water diffusion.

Various studies have been carried out to assess leukoaraiosis using DTI. Most of the studies were based on a comparison of the average DTI values between leukoaraiosis patients and healthy control groups (Helenius et al. 2002a; Jones et al. 1999; Rossi et al. 2010; Rowe Bijanki et al. 2013). There is a clear consensus among researchers that the measurement of leukoaraiosis using DTI displayed changes in the DTI parameter indices, specifically an increase in MD and a decrease in FA values. There are also studies in which volumetric measurement was used to assess leukoaraiosis, in which the total volume of leukoaraiosis in the whole brain was computed (Rossi et al. 2010; Silbert et al. 2008; Wright et al. 2008).

In this work, we attempt to observe tissue changes at each leukoaraiosis spot in an individual subject's brain. A characterisation parameter named lesion-to-normal appearing white matter ratio (LNR) is introduced in this study, which indexes the level of tissue damage at a leukoaraiosis region by comparing its MD with those of the normal surrounding tissues. This is due to an issue of whether the normal surrounding tissue is really normal or already changed slightly (Helenius et al. 2002b). In their study, Helenius et al. (2002b) showed an increased apparent diffusion coefficient (ADC) value of normalappearing white matter (NAWM) with the increased severity of leukoaraiosis. However, determining the absolute normal tissue surrounding each leukoaraiosis spot is very subjective and challenging. The LNR method is based on the fact that there are intra- and intersubject variabilities of MD values across different white matter regions (Ding et al. 2007; Hunsche et al. 2001; Löbel et al. 2009; Mohd Taib et al. 2015). Studies by Ding et al. (2007) on normal healthy subjects showed that the MD values measured in various white matter regions ranged from 69.57 to $82.64\left(\times 10^{-5} \mathrm{~mm}^{2} / \mathrm{s}\right)$. On the other hand, Hunsche et al. (2001) showed a range of MD values of $74.20-89.70\left(\times 10^{-5} \mathrm{~mm}^{2} / \mathrm{s}\right)$ for $2 \mathrm{~mm}$ slice thickness and $74.60-91.30\left(\times 10^{-5} \mathrm{~mm}^{2} / \mathrm{s}\right)$ for $5 \mathrm{~mm}$ slice thickness.

A study performed on children and adolescents of up to 20 years old by Löbel et al. (2009) found that the mean MD values ranged from 71.60 to $93.10\left(\times 10^{-5} \mathrm{~mm}^{2} / \mathrm{s}\right)$. Moreover, a study on 12 normal healthy control subjects showed a variation of mean MD across different brain regions from 77.00 to $83.00\left(\times 10^{-5} \mathrm{~mm}^{2} / \mathrm{s}\right.$ ) (Mohd Taib et al. 2015), whereas the data recorded from this study exhibited MD values of normal white matters from as low as $65.02 \times 10^{-5}$ to as high as $92.03 \times 10^{-5} \mathrm{~mm}^{2} / \mathrm{s}$ among all subjects, which were confirmed by other previous studies that used a similar 1.5 T MRI system (Ding et al. 2007; Löbel et al. 2009; Mohd Taib et al. 2015).

Therefore, taking this fact into account, the degree of tissue damage between lesions is different in the case of two lesion spots that have similar MD values but the NAWMs surrounding the lesions have different MD values (Figure 1).

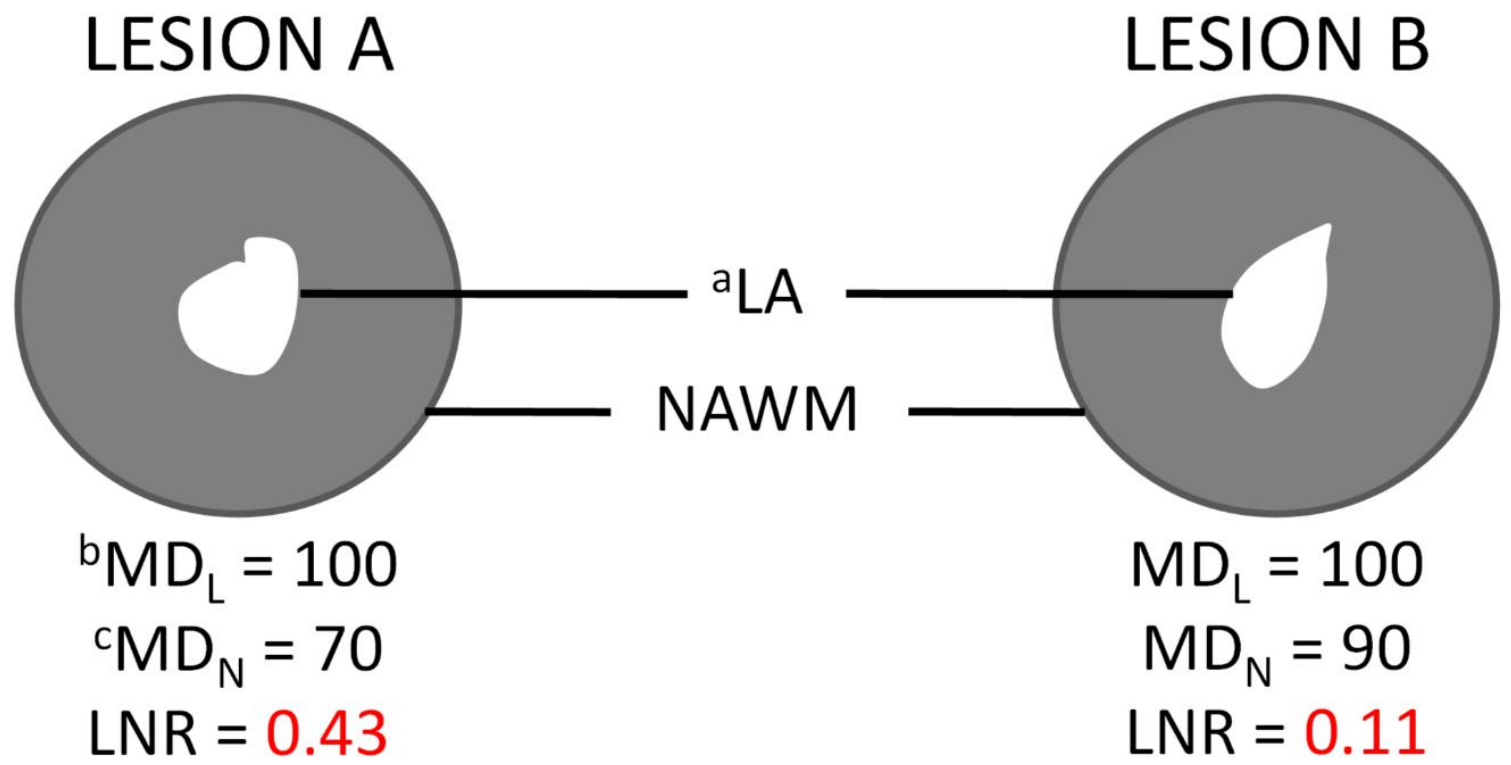

FIGURE 1. An example of two lesion spots, A and B. Both have similar MD values but taking into accounts the variability of its initial MD values, lesion A has a higher degree of tissue damage ( ${ }^{\mathrm{a} l e u k o a r a i o s i s}{ }^{\mathrm{b}} \mathrm{MD}$ of lesion ${ }^{\mathrm{c}} \mathrm{MD}$ of NAWM) 
As mentioned earlier, this work is focused mainly on characterising the leukoaraiosis tissue using MD, FA and the refined version of MD (LNR). It also assessed the correlation between MD, FA, and LNR with leukoaraiosis volume. A positive correlation between MD and LNR with leukoaraiosis volume (the larger the leukoaraiosis volume, the higher the MD and LNR values) is hypothesised. Apart from that, a negative correlation between FA and leukoaraiosis volume (the larger leukoaraiosis volume, the lower FA values) is also hypothesised.

\section{MATERIALS AND METHODS}

\section{MR IMAGES}

This is a retrospective study in which data images of 49 subjects were retrieved from the picture archiving and communication system (PACS). The data consist of T1weighted image (T1), T2-weighted image (T2), Fluidattenuated inversion recovery (FLAIR) and DTI images obtained using 1.5 Tesla MRI system (Signa HDxt, GE Healthcare). The subjects consisted of 20 males and 29 females aged between 39.5 and 67.6 (mean \pm SD: 54.5 \pm 7.1 ) years old when the scan was performed. They had undergone an MRI scan, and it was confirmed by a senior consultant radiologist that they had leukoaraiosis in the brain. This retrospective study was approved by the ethics committee of Universiti Sains Malaysia (USM/ JEPeM/17050265).

\section{MR IMAGING AND ANALYSIS}

T1, T2 and FLAIR images were acquired using the standard protocol in routine clinical brain imaging. The DTI data were acquired using the following protocols: pulse sequence, which consisted of the single-shot spin echo, echo-planar imaging (SS-EPI), TR: $13000 \mathrm{~ms}$,
TE: $90.1 \mathrm{~ms}$, b-value: 0 and $700 \mathrm{~s} / \mathrm{mm} 2,30$ directions with 3 sets of bo images. The images consisted of axial slices covering the whole brain and without signal averaging. The $2.5 \mathrm{~mm}$ isotropic voxel resolution was acquired via slice thickness: $2.5 \mathrm{~mm}$ with no interslice gap, matrix size: $96 \times 96$ (zero-filled and reconstructed to $256 \times 256$ ), and field of view (FOV): $245 \mathrm{~mm} \times 245$ $\mathrm{mm}$ (Mohd Taib et al. 2017). All the images were sent to independent workstations for post-processing and further analysis. Post-processing and analysis were carried out using Osirix software version 4.1.2 (Rosset et al. 2004).

\section{Region of interest and measurement of volume}

FLAIR images for each subject were examined slice by slice, and all the leukoaraiosis regions in the subcortical and deep white matter area were selected for placement of the region of interest (ROI). Leukoaraiosis volume was manually measured on the axial FLAIR images as depicted in Figure 2. A freehand ROI was carefully drawn at the lesion edge. For the leukoaraiosis region that appears on multiple slices, the ROI was drawn on each slice where the lesion appears. Then, the lesion volume was computed using the software. The same steps were repeated for each lesion spot in every subject.

\section{Measurement of DTI values}

For the measurement of the DTI values, the ROIs were identified on the FLAIR images and confirmed by a senior consultant radiologist. That particular location was simultaneously coordinated on the MD maps as indicated in Figure 2. The ROI was then drawn on the MD maps at the exact corresponding location with the FLAIR images. One ROI was placed in the area of leukoaraiosis and labelled as Lesion (L). Then, another ROI was placed on a normal-appearing white matter near the lesion spot.

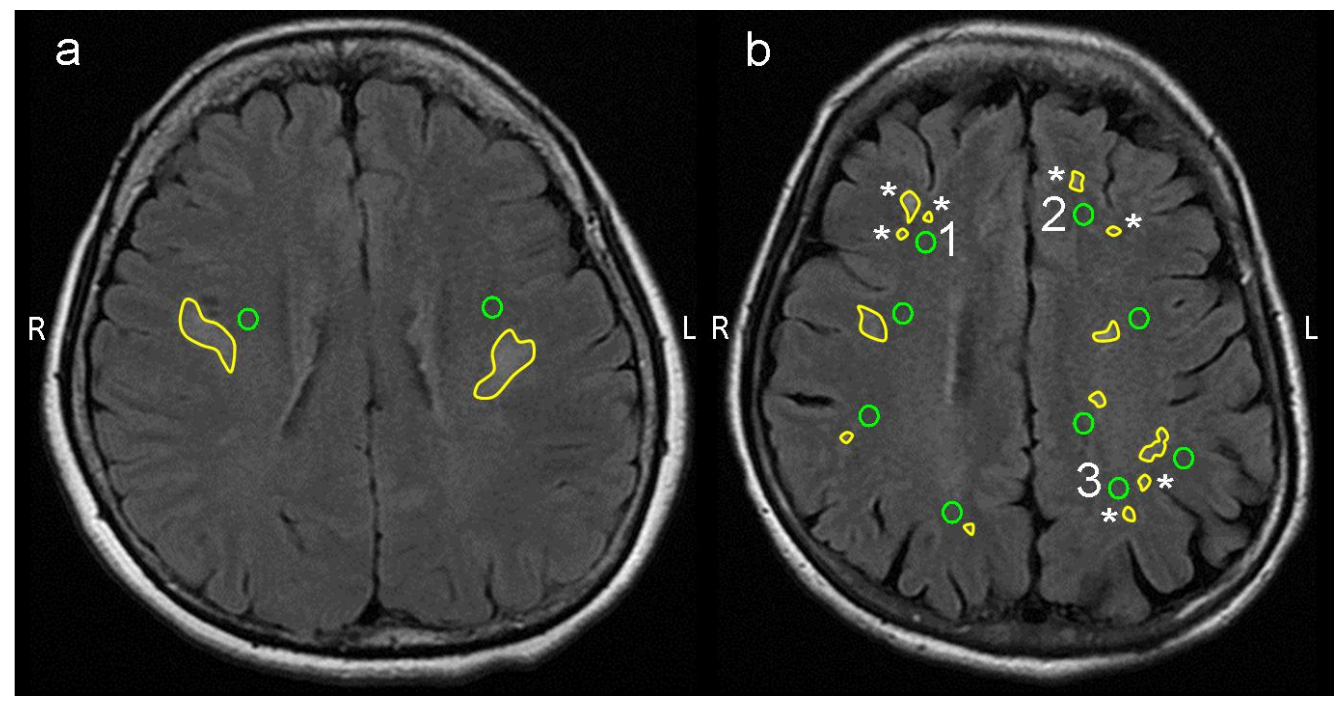

FIGURE 2. An example of ROI placement on FLAIR images of a subject with a) big lesions and b) small lesions. 'L' ROIs are represented by the yellow freehand drawings ROI while ' $\mathrm{N}$ ' ROIs are represented by the green circles located near to the lesion. In (b), some 'N' ROIs (labelled 1, 2, and 3) correspond to the multiple 'L' ROIs (marked with asterisks) 
This ROI was labelled as Normal $(N)$, which describes the NAWM surrounding the lesion. The $N$ ROI was carefully placed at a distance of at least 5 pixels from the lesion boundary to avoid the mixed region of the normal white matter with leukoaraiosis. All $L$ ROIs were drawn according to the shape of the lesion, and as a result, the size varies according to the lesion. However, $N$ ROIs were standardised to a size of $0.30 \pm 0.02 \mathrm{~cm}^{2}$ (Figure 2 ). For the leukoaraiosis region that appears on multiple slices, $L$ ROI and the corresponding $N$ ROI were placed at a slice at the centre of the lesion. All the ROIs were copied onto the FA maps. All the DTI values for all the ROIs were recorded and the same steps were repeated for every subject.

\section{Calculation of $L N R$}

LNR was determined using (1):

$$
\mathrm{LNR}=\frac{\mathrm{MD}_{\mathrm{L}}-\mathrm{MD}_{\mathrm{N}}}{\mathrm{MD}_{\mathrm{N}}}
$$

where $\mathrm{MD}_{\mathrm{L}}$ is the mean MD of the $L \mathrm{ROI}$; and $\mathrm{MD}_{\mathrm{N}}$ is the mean MD of the $N$ ROI.

\section{STATISTICAL ANALYSIS}

The Shapiro-Wilk test of normality suggested that all the data were not normally distributed except for the MD of NAWM $(\mathrm{S}-\mathrm{W}=.996, \mathrm{df}=274, \mathrm{p}=.627)$. Consequently, a nonparametric test, Spearman's rho, was performed to investigate the relationship between MD, FA, and LNR with leukoaraiosis volume for all 274 ROI data. For each correlation analysis, $\mathrm{p}<0.05$ was considered statistically significant.

\section{RESULTS AND DISCUSSION}

\section{OUTLIERS}

The results showed that two data exhibited extremely high MD values. An outlier test was performed on the entire datasets, and it was then confirmed that these two data were outliers. All the datasets were reviewed, and it was established that the outliers were not due to any experimental mistake. Therefore, these two data were retained for further analysis, in which case, two analyses were performed to take into account the data with and without the outliers. The results showed that the outliers did not change the correlation results significantly as shown in the results below.

\section{CHARACTERIZATION OF LEUKOARAIOSIS AND NAWM USING MD AND FA}

Table 1 shows a descriptive summary of the MD and FA values of all ROIs. On the whole, the leukoaraiosis tissues were found to exhibit higher MD and lower FA values than the NAWM tissues (Figure 3), which is in agreement with previous studies (Helenius et al. 2002a; Jones et al. 1999; Maniega et al. 2015; Rossi et al. 2010; Rowe Bijanki et al. 2013). MD is the DTI parameter index that gives the information on the mean displacement of water diffusion in white matter tissues, where a higher MD indicates a greater molecular diffusion. On the other hand, FA provides detailed information on the directionality of the water diffusion in which a higher FA indicates a higher directionality. However, FA is very dependent on voxel size and fibre architecture (Oouchi et al. 2007), and thus may vary extensively across all parts of the white matter. Therefore, MD rather than FA has been selected as an indicator for comparison between the damaged and normal tissues in each subject.

TABLE 1. Summary of MD and FA values measured at all ROIs

\begin{tabular}{lcccc}
\hline Parameters & Min & Max & Mean & SD \\
\hline Leukoaraiosis & & & & \\
Volume $(\mathrm{cm} 3)$ & 0.01 & 10.37 & 0.96 & 1.63 \\
MD $\left(\times 10^{-5} \mathrm{~mm}^{2} / \mathrm{s}\right)$ & 87.46 & 213.95 & 103.97 & 12.32 \\
FA & 0.08 & 0.70 & 0.31 & 0.08 \\
NAWM & & & & 4.76 \\
MD $\left(\times 10^{-5} \mathrm{~mm}^{2} / \mathrm{s}\right)$ & 65.02 & 92.03 & 79.30 & 0.09 \\
FA & 0.22 & 0.69 & 0.41 & \\
\hline
\end{tabular}




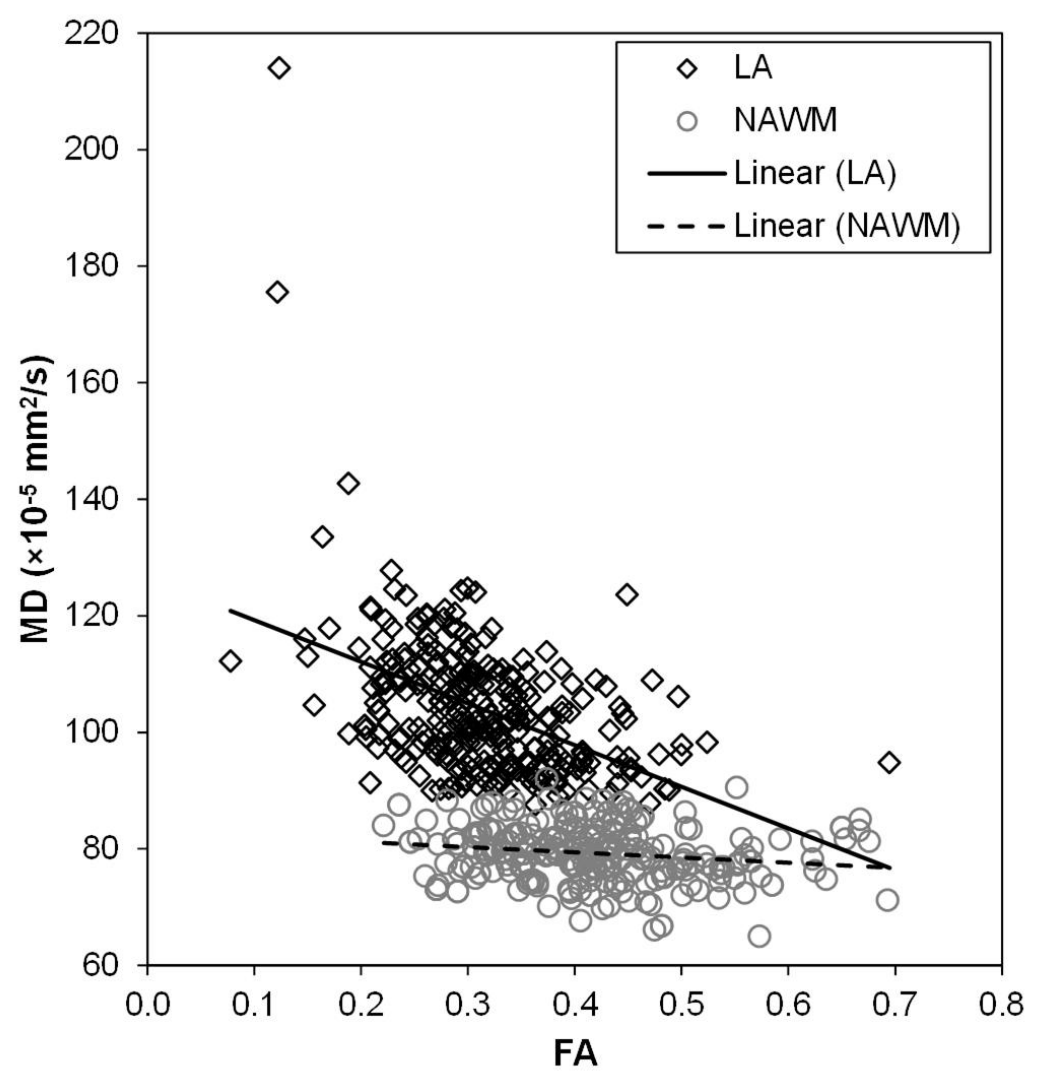

FIGURE 3. Distributions of MD and FA of leukoaraiosis (LA) and normal-appearing white matter (NAWM) for all 274 ROI data

CHARACTERIZATION OF LEUKOARAIOSIS USING LNR The calculated LNR values are in the range of 0.041.63. The LNR describes the ratio of tissue destruction relative to the normal surrounding tissue. In Figure 4, a leukoaraiosis spot with a higher LNR shows a lower FA. This finding agrees with the original parameter of LNR, which is MD. This finding corresponds to the degree of tissue destruction where the higher the ratio of the mean displacement of water molecules in leukoaraiosis over normal surrounding tissues, the lower the FA value. A low FA value of leukoaraiosis indicates less directional movement (or more scattered movement) of water molecules inside the tissue. Such occurrence was explained by studies on various pathological aspects that included the degradation of myelin and microtubules, perivascular space widening, gliosis and loss of axons (Chanraud et al. 2010; Marner et al. 2003; O'Sullivan 2008).

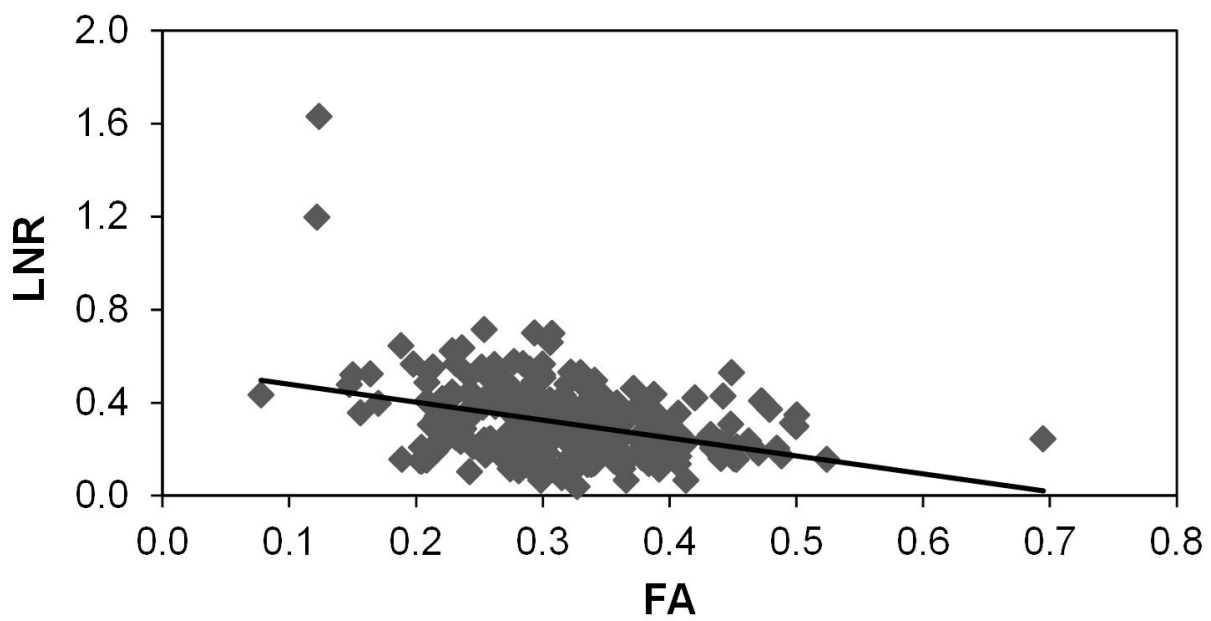

FIGURE 4. Distributions of of LNR and FA of leukoaraisis for all 274 ROI data 


\section{ASSOCIATION OF MD, LNR AND FA WITH VOLUME OF LEUKOARAIOSIS}

The correlation analysis shows a very weak negative correlation $(r=-0.196 ; p=0.001)$ between MD and leukoaraiosis volume, as presented in Table 2 and Figure 5(a). These results take into account only the MD values of the leukoaraiosis tissue. However, if we consider the variable nature of the MD values of the surrounding normal tissue using LNR, the correlation between LNR and lesion volume is found to be not significant $(r=-$
0.055; $p=0.368$ ) (Figure 5(b)), which is against the hypothesis. These results indicate that there are small leukoaraiosis spots that exhibit higher MD values and vice versa. Furthermore, a very weak correlation is also found between FA and leukoaraiosis volume ( $r=$ 0.268; $p<0.001$ ) as shown in Figure 5(c). This finding shows that a smaller leukoaraiosis may have FA values, which indicate a more scattered movement of the water molecules.

TABLE 2. Correlation between MD, LNR and FA with leukoaraisosis volume

\begin{tabular}{lccc}
\hline Correlation & With/without outliers & Correlation coefficient & Significance \\
\hline MD - volume & with & -0.196 & $p=0.001$ \\
without & -0.217 & $p<0.001$ \\
LNR - volume & with & -0.055 & $p=0.368$ \\
& without & -0.073 & $p=0.227$ \\
FA - volume & with & 0.268 & $p<0.001$ \\
& withou & 0.286 & $p<0.001$ \\
\hline
\end{tabular}

a

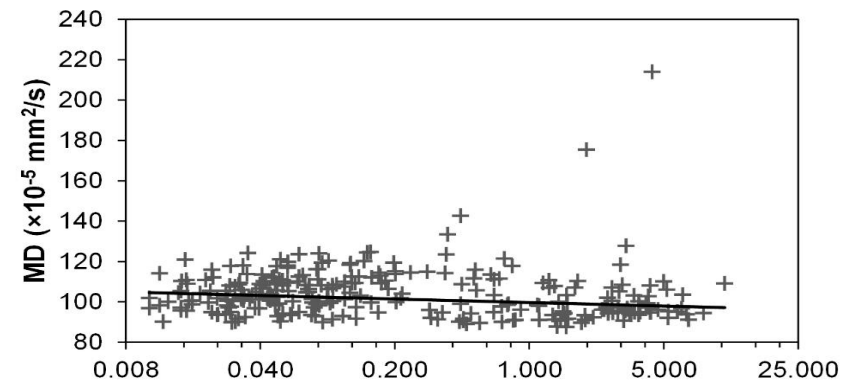

b

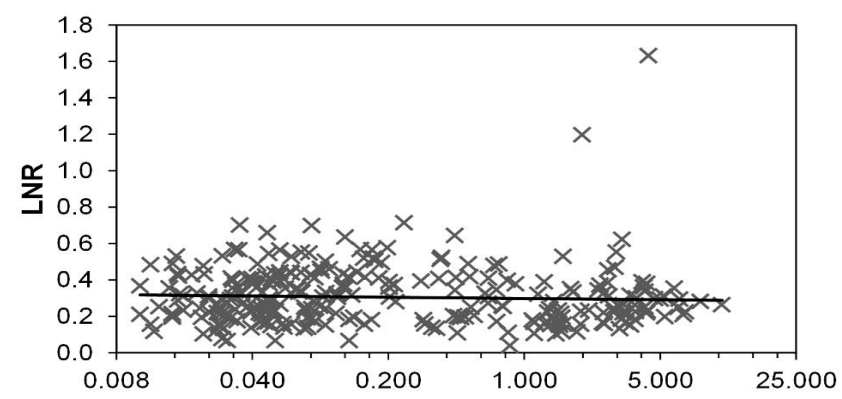

C

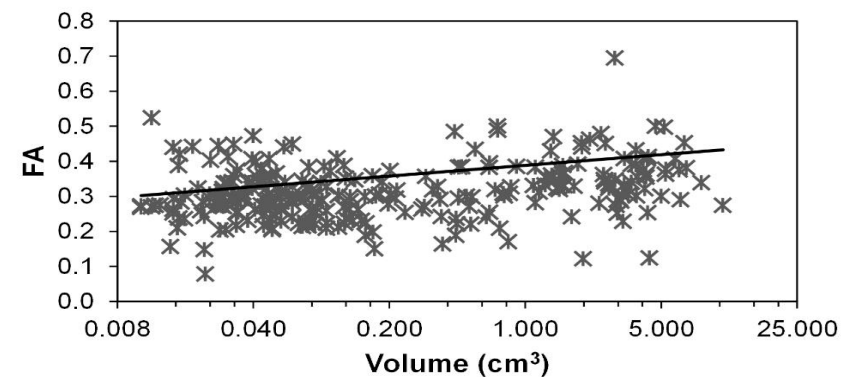

FIGURE 5. Correlation between (a) MD and leukoaraiosis volumea, (b) LNR and leukoaraiosis volume, and (c) FA and leukoaraiosis volume (aVolumes are displayed in Log5 scale) 
Ropele et al. (2009), who measured the severity of tissue damage using ADC and magnetization transfer ratio (MTR), suggested that there is a low correlation between the ADC and MTR values for the lesion volume $(r=0.40 ; p=0.0001)$ whereas there was no association between MTR and the lesion volume. This correlation was not significantly different from our findings, particularly on the correlation between the MD values and the leukoaraiosis volume except that our finding shows a negative correlation. The most possible reason underlying this result is that there is a fairly large distribution of small lesions in the data that affected the direction of the relationship. An inspection carried out on the acquired data (274 ROIs) found that $73 \%$ of all the ROIs consisted of those of less than $1.0 \mathrm{~cm} 3$ size which is quite small compared with the other ROIs.

\section{LIMITATION}

The use of LNR in this study shows that there is no relationship between MD and leukoaraiosis volume. LNR takes into account the initial MD of a normal tissue in classifying the severity of tissue damage in a specific leukoaraiosis spot. It makes the correlation more accurate since the MD variability of normal tissues is eliminated. However, the severity can be seen from various perspectives. In addition to the quantitative parameters (MD, LNR, FA, \& MTR), severity can also be seen from the cognitive effect and functional perspectives. Nevertheless, this study focuses only on the quantitative parameters, particularly MD and LNR, in defining the severity of leukoaraiosis. The effect of lesion volume on cognition and function is beyond the scope of this study.

\section{CONCLUSION}

On the basis of the characterisation of leukoaraiosis at all 274 ROIs and correlation analysis using LNR, it is concluded that leukoaraiosis volume does not necessarily portray the severity of white matter damage. In this study, we consistently showed a considerably weak association between MD and leukoaraiosis volume. Furthermore, no association was found between LNR and leukoaraiosis volume. This study suggests that the degree of changes in the leukoaraiosis tissue is not associated with the size of the leukoaraiosis.

\section{ACKNOWLEDGEMENTS}

This study was funded by Universiti Sains Malaysia under USM short-term grant (304/PPSP/6315095).

\section{REFERENCES}

Chanraud, S., Zahr, N., Sullivan, E.V. \& Pfefferbaum, A. 2010. MR diffusion tensor imaging: A window into white matter integrity of the working brain. Neuropsychol. Rev. 20(2): 209-225

Ding, X.Q., Finsterbusch, J., Wittkugel, O., Saager, C., Geobell,
E., Fitting, T., Ulrich, G., Zeumer, H. \& Fiehler, J. 2007. Apparent diffusion coefficient, fractional anisotropy and T2 relaxation time measurement: Does the field strength matter? Clin. Neuroradiol. 17: 230-238.

Fazekas, F., Barkhof, F., Wahlund, L.O., Pantoni, L., Erkinjuntti, T., Scheltens, P. \& Schmidt, R. 2002. CT and MRI rating of white matter lesions. Cerebrovasc. Dis. 13(2): 31-36.

Grueter, B.E. \& Schulz, U.G. 2011. Age-related cerebral white matter disease (leukoaraiosis): A review. Postgrad. Med. J. 88(1036): 79-87.

Helenius, J., Soinne, L., Salonen, O., Kaste. \& Tatlisumak, T. 2002a. Leukoaraiosis, ischemic stroke, and normal white matter on diffusion-weighted MRI. Stroke 33(1): 45-50.

Helenius, J., Soinne, L., Perkiö, J., Salonen, O., Kangasmäki, A., Kaste, M., Richard, A.D.C., Hannu, J.A. \& Tatlisumak, T. 2002b. Diffusion-weighted MR imaging in normal human brains in various age groups. AJNR Am. J. Neuroradiol. 23(2): 194-199.

Hunsche, S., Moseley, M.E., Stoeter, P. \& Hedehus, M. 2001. Diffusion-tensor MR imaging at 1.5 and $3.0 \mathrm{~T}$ : Initial observations. Radiology 221(2): 550-556.

Jones, D.K., Lythgoe, D., Horsfield, M.A., Simmons, A., Williams, S.C.R. \& Markus, H.S. 1999. Characterization of white matter damage in ischemic leukoaraiosis with diffusion tensor MRI. Stroke 30(2): 393-397.

Löbel, U., Sedlacik, J., Güllmar, D., Kaiser, W.A., Reichenbach, J.R. \& Mentzel, H.J. 2009. Diffusion tensor imaging: The normal evolution of ADC, RA, FA, and eigenvalues studied in multiple anatomical regions of the brain. Neuroradiology 51(4): 253-263.

Maniega, S.M., Hernández, M.C.V., Clayden, J.D., Royle, N.A., Murray, C., Morris, Z., Aribisala, B.S., Gow, A.J., Starr, J.M., Bastin, M.E., Deary, I.J. \& Wardlaw, J.M. 2015. White matter hyperintensities and normal-appearing white matter integrity in the aging brain. Neurobiol. Aging 36(2): 909-918.

Marner, L., Nyengaard, J.R., Tang, Y. \& Pakkenberg, B. 2003. Marked loss of myelinated nerve fibers in the human brain with age. J. Comp. Neurol. 462(2): 144-152.

Mohd Taib, N.H., Wan Abdullah, A.K., Shuaib, I.L., Magosso, E. \& Mat Isa, S. 2017. Determination of optimum combination of voxel size and b-value for brain diffusion tensor imaging. Sains Malaysiana 46(1): 67-74.

Mohd Taib, N.H., Wan Abdullah, A.K., Shuaib, I.L., Magosso, E. \& Mat Isa, S. 2015. Diffusion tensor imaging of leukoaraiosis, normal appearing brain tissue, and normal brain tissue. Malaysian Journal of Medicine and Health Sciences 11(1): 1-10.

O’Sullivan, M. 2008. Leukoaraiosis. Prac. Neurol. 8(1): 26-38.

Oouchi, H., Yamada, K., Sakai, K., Kizu, O., Kubota, T., Ito, H. \& Nishimura, T. 2007. Diffusion anisotropy measurement of brain white matter is affected by voxel size: Underestimation occurs in areas with crossing fibers. AJNR Am. J. Neuroradiol. 28(6): 1102-1106.

Pantoni, L., Simoni, M., Pracucci, G., Schmidt, R., Barkhof, F. \& Inzitari, D. 2002. Visual rating scales for age-related white matter changes (Leukoaraiosis). Stroke 33(12): 2827-2833.

Ropele, S., Seewann, A., Gouw, A.A., van der Flier, W.M., Schmidt, R., Pantoni, L., Inzitari, D., Erkinjuntti, T., Scheltens, P., Wahlund, L.O., Waldemar, G., Chabriat, H., Ferro, J., Hennerici, M., O'Brien, J., Wallin, A. \& Langhorne, P. 2009. Quantitation of brain tissue changes associated with white matter hyperintensities by diffusion-weighted and magnetization transfer imaging: The LADIS (leukoaraiosis 
and disability in the elderly) study. J. Magn. Reson. Imaging 29(2): 268-274

Rosset, A., Spadola, L. \& Ratib, O. 2004. OsiriX: An open-source software for navigating in multidimensional DICOM images. J. Dig. Imaging 17(3): 205-216.

Rossi, M., Jason, E., Marchesotti, S., Dastidar, P., Ollikainen, J. \& Soimakallio, S. 2010. Diffusion tensor imaging correlates with lesion volume in cerebral hemisphere infarctions. BMC Med. Imaging 10(1): 1-11.

Rowe, B.K., Arndt, S., Magnotta, V.A., Nopoulos, P., Paradiso, S., Matsui, J.T., Johnson, H.J. \& Mosera, D.J. 2013. Characterizing white matter health and organization in atherosclerotic vascular disease: A diffusion tensor imaging study. Psychiat. Res. 214(3): 389-394.

Silbert, L.C., Nelson, C., Howieson, D.B., Moore, M.M. \& Kaye, J.A. 2008. Impact of white matter hyperintensity volume progression on rate of cognitive and motor decline. Neurology 71(2): 108-113.

Wright, C.B., Festa, J.R., Paik, M.C., Schmiedigen, A., Brown, T.R., Yoshita, M., DeCarli, C., Sacco, R. \& Stern, Y. 2008. White matter hyperintensities and subclinical infarction: Associations with psychomotor speed and cognitive flexibility. Stroke 39(3): 800-805.
Nur Hartini Mohd Taib*, Wan Ahmad Kamil Wan Abdullah \& Ahmad Hadif Zaidin Samsudin

Department of Radiology

School of Medical Sciences

Universiti Sains Malaysia

Health Campus, 16150 Kubang Kerian, Kelantan Darul Naim Malaysia

Ibrahim Lutfi Shuaib, Enrico Magosso \& Suzana Mat Isa Advanced Medical and Dental Institute

Universiti Sains Malaysia

13200 Kepala Batas, Penang

Malaysia

Muhammad Nur Salihin Yusoff

Medical Radiation Programme

School of Health Sciences

Universiti Sains Malaysia

16150 Kubang Kerian, Kelantan Darul Ehsan

Malaysia

*Corresponding author; email: nhartini@usm.my

Received: 13 February 2019

Accepted: 20 December 2019 